\title{
PENGOLAHAN EFLUEN IPAL KOMUNAL RT 4 RW 8 KELURAHAN BARENG DENGAN HIDROPONIK
}

\author{
Evy Hendriarianti ${ }^{1)}$, Hardianto ${ }^{2)}$, Yusuf Ismail Nakhoda ${ }^{3)}$ \\ ${ }^{1,2)}$ Program Studi Teknik Lingkungan ITN Malang \\ E-mail: 1)evyhendriarianti@lecturer.itn.ac.id, hardianto@lecturer.itn.ac.id ${ }^{2)}$ \\ ${ }^{3)}$ Program Studi Teknik Elektro ITN Malang \\ E-mail: yusuf_nakhoda@lecturer.it.ac.id ${ }^{3)}$
}

\begin{abstract}
Abstrak
Lokasi mitra kegiatan abdimas di RT 4 RW 8 Kelurahan Bareng mempunyai fasilitas IPAL Komunal yang dikelola masyarakat setempat dalam bentuk Kelompok Sanitasi Masyarakat (KSM) Purworupo.

Pada kegiatan abdimas ini akan dilakukan pemberian materi pengolahan efluen IPAL Komunal dengan teknik hidroponik sehingga bisa mengurangi kandungan nutrien efluen sebelum dibuang ke badan air penerima. Kegiatan ini merupakan kelanjutan dari penelitian internal sebelumnya yang telah dilaksanakan pada tahun 2017.

Kegiatan pemanfaatan efluen IPAL Komunal sebagai media tanaman hidroponik di RT 4 RW 8 Kelurahan Bareng mempunyai prospek pengembangan positif dalam upaya pemanfaatn efluen IPAL Komunal dan pengendalian kualitas air sungai. Permasalahan yang dihadapi dalam pelaksanaan kegiatan abdimas ini adalah fluktuasi kualitas efluen IPAL Komunal yang menyebabkan ketidak stabilan proses pengolahan dengan teknik hidroponik. Kondisi ini beresiko pada pertumbuhan tanaman dan kualitas efluen dari hasil pengolahan air limbah dengan teknik hidroponik. Faktor kekuatan dalam kegiatan ini pendanaan dari ITN Malang, hasil riset sebelumnya, informasi aplikasi teknologi fitoremediasi air limbah dan kesediaan masyarakat sebagai mitra abdimas. Sedangkan kelemahan dalam kegiatan abdimas ini keterbatasan waktu warga dalam perencanaan jadwal sosialisasi awal dan keterbatasan ruang untuk penempatan reaktor hidroponik.
\end{abstract}

Kata Kunci: abdimas, efluen IPAL Komunal, hidroponik

\section{PENDAHULUAN}

Kelurahan Bareng Kecamatan Klojen Kota Malang merupakan wilayah pusat kota Malang dengan kepadatan penduduk tinggi. Timbulan air limbah dan sampah menjadi permasalahan yang belum sepenuhnya bisa tertangani dengan layak.

Dari informasi ketua RT 04 RW 08 Kelurahan Bareng yang berkunjung ke kampus ITN Malang dan surat permohonan bantuan dan kerjasama pengembangan kampung sanitasi dari ketua RT 04 RW 08 Kelurahan Bareng, diperoleh informasi bahwa telah ada fasilitas IPAL Komunal seperti pada gambar 1. Telah dilakukan penelitian dari Universitas Brawijaya pada tahun 2017 tentang pemanfaatan lumpur dari IPAL Komunal menjadi pakan lele. Keinginan selanjutnya mengharapkan efluen IPAL Komunal bisa dimanfaatkan untuk pupuk organik.

Keinginan masyarakat RT4 RW 08 Kelurahan ini sejalan dengan program pemerintah di bidang sanitasi. Program pembangunan berkelanjutan yang dikenal sebagai $S D G$ 's mempunyai goal ke 6 yaitu menjamin ketersediaan dan pengelolaan berkelanjutan air dan sanitasi bagi semua. Goal ini ditargetkan tercapai pada tahun 2030. Terkait dengan target ini, Pemerintah melalui Kementerian Cipta Karya mempunyai kebijakan dan strategi $100 \%$ akses sanitasi layak (air limbah domestik, sampah dan drainase lingkungan). Melalui Direktorat Penyehatan Lingkungan Pemukiman, pemerintah mempunyai kebijakan penanganan air limbah, sampah dan drainase. Salah satu aspek kebijakannya adalah peningkatan kemitraan dan kerjasama antar lembaga.

Dengan latar belakang penelitian pemanfaatan efluen IPAL Komunal sebagai media hidroponik (2017) dan permohonan masyarakat kepada kami, melaksanakan kegiatan abdimas untuk pemanfaatan efluen IPAL Komunal untuk media tanam hidroponik.

Permasalahan masih tingginya kandungan nutrien efluen IPAL Komunal yang dibuang pada badan air penerima dapat menyebabkan pencemaran air. Pengkayaan nutrien pada badan air dapat menyebabkan badan air subur sehingga beresiko pada pertumbuhan ganggang yang tidak terkendali (blooming algae). Hal ini bisa menimbulkan berkurangan suplai oksigen terlarut dari proses reaerasi dan fotosistensa tanaman air. 
Dengan melihat permasalahan diatas, maka perlu dilakukan upaya penurunan kandungan nutrien efluen IPAL Komunal melalui pengolahan dengan hidroponik.

\section{METODE KEGIATAN}

\section{Metode Pendekatan Sosial}

Dasar pemikiran dari mitra RT 4 RW 8 kelurahan Bareng adalah dengan melihat potensi hidroponik sebagai teknologi fitoremediasi pengolahan efluen dengan kandungan nutrien sebagai nutrisi tanaman hidroponik.

Dalam pembuatan reaktor hidroponik pada lokasi IPAL Komunal diperlukan data dan informasi yang terpercaya dari mitra. Oleh karena itu kerjasama tim dan mitra sangat melalui pendekatan sosial yang intensif berperan dalam mewujudkan reaktor hidroponik untuk pengolahan efluen yang diharapkan.

\section{Rencana Kegiatan}

Kegiatan abdimas ini mempunyai rencana kegiatan sebagai berikut.

1. Survei awal

2. Koordinasi desain reaktor.

3. Pengumpulan data dan informasi.

4. Pembuatan reaktor

5. Persiapan tanaman.

6. Sosialisasi operasi dan pemeliharaan reaktor hidroponik.

\section{Partisipasi Mitra}

Partisipasi yang diharapkan dari mitra warga

RT 4 RW 8 Kelurahan Bareng dalam pelaksanaan program Abdimas meliputi :

1. Mendampingi dalam survei lapangan dan pemasangan reaktor hidroponik.

2. Memberikan data dan informasi yang akurat.

3. Memberikan masukan dalam proses pemasangan reaktor hidroponik.

\section{HASIL DAN PEMBAHASAN}

\section{Prospek Umum Pengembangan Kegiatan}

Kegiatan pemanfaatan efluen IPAL Komunal sebagai media tanaman hidroponik di RT 4 RW 8 Kelurahan Bareng mempunyai prospek pengembangan positif dalam upaya pengendalian kualitas air sungai. Hal ini terkait dengan pembuangan efluen IPAL Komunal dengan kandungan nutrien $\mathrm{N}$ yang tinggi ke sungai sebagai badan air penerima. Pemanfaatan efluen IPAL Komunal sebagai media tanam hidroponik memerlukan kajian lebih lanjut dalam hal jenis tanaman yang bermanfaat sebagai penahan erosi mengingat sebagian besar lokasi IPAL Komunal terletak pada bantaran sungai.

Kegiatan ini sangat memerlukan peran aktif masyarakat selaku pengelola IPAL Komunal dan perguruan tinggi dalam upaya pengembangan teknologi fitoremediasi. Sehingga prospek pengembangan kegiatan bermanfaat dalam upaya pengendalian kualitas air sungai, peningkatan kinerja pengolahan IPAL Komunal dan keterlibatan perguruan tinggi dalam permasalahan lingkungan.

\section{Potensi, Masalah, Kekuatan dan Kelemahan}

\section{Potensi}

Potensi penggunaan efluen IPAL Komunal sebagai media tanam hidroponik didasarkan pada kondisi sebagai berikut :

a. Keberadaan IPAL Komunal sebagai upaya Pemerintah dalam program pengelolaan air limbah domestik menuju akses sanitasi $100 \%$.

Berikut ini informasi IPAL Komunal di kota Malang dan di RT 4 RW 8 Kelurahan Tlogomas.

Tabel 1. IPAL Komunal di Kota Malang

\begin{tabular}{|c|c|c|c|c|c|c|}
\hline so. & STMER DAXA & $\operatorname{stan}$. of & $\begin{array}{l}\text { KAPASTAS } \\
\text { (KK5) }\end{array}$ & 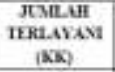 & PEXGEOLA' & Tantx \\
\hline$t$ & 5 madm & $i$ & 560 & 110 & K53 & $\operatorname{Ins}$ \\
\hline \multirow{3}{*}{2} & \multirow{3}{*}{ PKK Koou taling } & 2 & 100 & 50 & \multirow{3}{*}{$\mathrm{BSH}$} & \multirow{3}{*}{$1958-1999$} \\
\hline & & 1 & 150 & 100 & & \\
\hline & & 1 & 200. & 150 & & \\
\hline 3 & NAN & 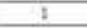 & 150 & 80 & $\mathrm{XSM}$ & 1500 \\
\hline \multirow{2}{*}{+} & \multirow{2}{*}{ Bak Dena } & I & 6000 & 800 & LML & 2600 \\
\hline & & $i$ & 10.600 & 1,550 & XSMC & 2000 \\
\hline 3 & DAK-APIN & $\pi$ & 100 & $10-10$ & KSG & $2000-2014$ \\
\hline a. & $\begin{array}{l}\text { DAK NOBN } \\
\text { Peprat }\end{array}$ & 1 & 900 & 200 & $\mathrm{~K} \times \mathrm{M}$ & 2011 \\
\hline 2 & USRI & 10 & $x$ & $19-136$ & $\overline{M P} ?$ & $211-2001$ \\
\hline
\end{tabular}

Keterangan : *) KSM, Kelompok Swadaya Masyarakat; KPP, Kelompok Pemanfaat dan Pemelihara

Sumber : Diolah dari data DKP Kota Malang dan BKBPM Kota Malang, 2014-2015.
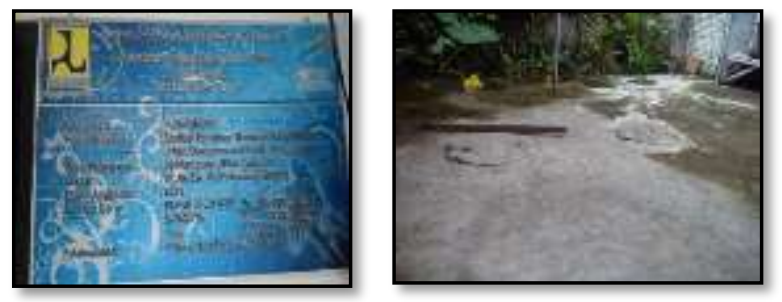

Gambar 1. IPAL Komunal RT 4 RW 8 Kelurahan Bareng

b. Kualitas efluen dari pengolahan air limbah domestik mengandung nutrien $\mathrm{N}$ yang berguna sebagai nutrisi tanaman.

c. Teknik fitoremediasi dan hidroponik yang semakin berkembang aplikasinya.

Reaktor Hidroponik terdiri atas kerangka sebagai penyangga reaktor dan reaktor sebagai 
tempat tumbuh tanaman. Kerangka terbuat dari kayu dan berisi 3 tingkat. Reaktor terbuat dari fiber berjumlah 3 buah dalam satu unit. Dimensi kerangka dan reaktor dibuat $1500 \mathrm{~cm}^{2}$.

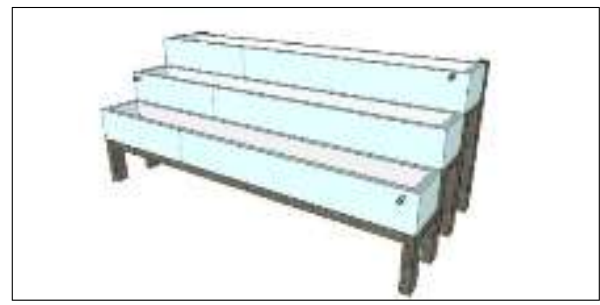

Gambar 2. Reaktor Hidroponik

d. Peran serta aktif masyarakat dalam upaya pengelolaan lingkungan.

Peran aktif warga tampak pada kegiatan sosialisasi hidroponik dengan media efluen IPAL Komunal yang dilaksanakan pada hari Minggu tanggal 16 Desember 2018 dengan mendatangkan narasumber Ibu Beiby Voijant Tangahu, dosen Prodi Teknik Lingkungan ITS Surabaya yang kompeten di bidang Fitoremediasi. Acara sosialisasi berlangsung lancar dan dihadiri oleh Bapak Lurah Bareng. Harapan warga yang diwakili oleh Bapak Juariyanto selaku ketua RT 4 RW 8 Kelurahan Bareng dan Bapak Lurah adalah keberlanjutan kegiatan abdimas dalam pengelolaan lingkungan sehat. Berikut ini dokumentasi kegiatan sosialisasi tersebut.

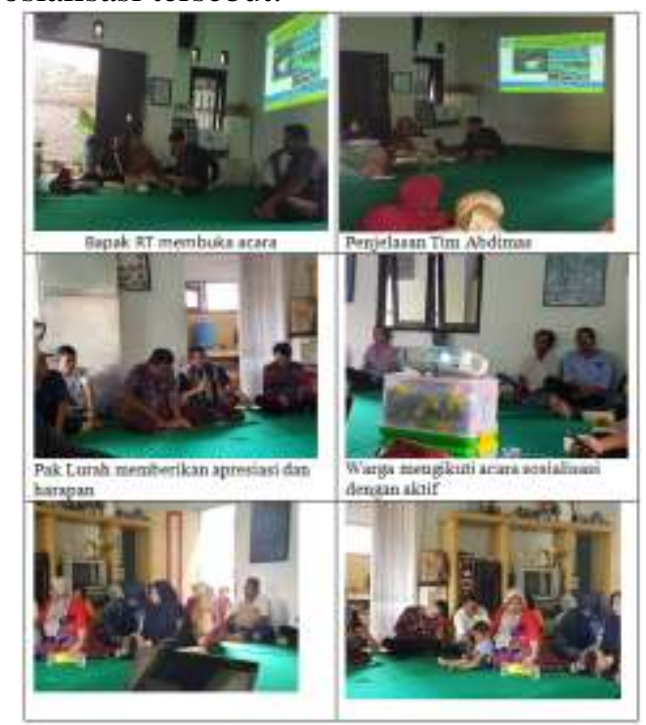

Gambar 3. Kegiatan Sosialisasi

\section{Masalah}

Permasalahan yang dihadapi dalam pelaksanaan kegiatan abdimas ini adalah fluktuasi kualitas efluen IPAL Komunal yang menyebabkan ketidak stabilan proses pengolahan dengan teknik hidroponik. Kondisi ini beresiko pada pertumbuhan tanaman dan kualitas efluen dari hasil pengolahan air limbah dengan teknik hidroponik.

\section{Kekuatan}

a. Program pendanaan kegiatan abdimas ITN Malang.

Hasil penelitian terkait pada lokasi abdimas yang dilaksanakan pada tahun sebelumnya. Berikut ini gambaran pertumbuhan tanaman kangkung dan selada sampai hari ke -14.

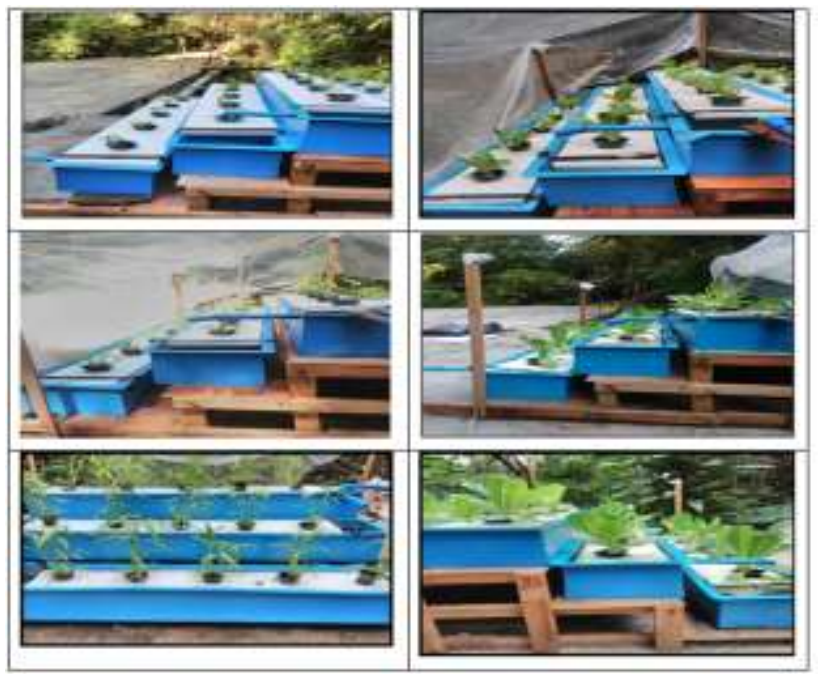

Gambar 3. Pertumbuhan Kangkung dan Selada hari ke 0,7 dan 14

b. Ketersediaan informasi aplikasi fitroremediasi untuk pengolahan lanjutan air limbah domestik.

c. Kesediaan masyarakat dalam bentuk dukungan informasi dan tenaga.

\section{Kelemahan}

Keterbatasan ruang untuk penempatan reaktor hidroponik pada lokasi setelah outlet IPAL Komunal.

\section{Telaah Kesiapan Fisik dan Non Fisik}

Dalam perancangan Kampung Wisata Kreatif RW 2 Bakalan Krajan telah diidentifikasi faktorfaktor yang menjadi indikator dalam kesiapan mewujudkan perancangan ini. Berikut ini kriteria kesiapan untuk parameter fisik dan non fisik.

Tabel 2. Kriteria Kesiapan Fisik

\begin{tabular}{|c|c|c|c|c|c|}
\hline no. & KRITERIA & $\begin{array}{l}\text { Sudah ada } \\
\text { tidak perla } \\
\text { diperbaiki } \\
\text { (skor 4) }\end{array}$ & $\begin{array}{l}\text { Ada perlu } \\
\text { diperbaiki } \\
\text { (skor 3) }\end{array}$ & $\begin{array}{c}\text { Tidak } \\
\text { ada, ada } \\
\text { lahas } \\
\text { (Skor 2) }\end{array}$ & $\begin{array}{l}\text { Tidak ada } \\
\text { dan tidak } \\
\text { ada Laban } \\
\text { (sker1) }\end{array}$ \\
\hline 1 & $\begin{array}{l}\text { Lahan unfuk } \\
\text { penemustan } \\
\text { teakior } \\
\text { hidroponik }\end{array}$ & & $v$ & & \\
\hline 2 & Jalan akses & & $\sqrt{ }$ & & \\
\hline & \multirow{2}{*}{$\begin{array}{l}\text { JUMLAH } \\
\text { SKOR }\end{array}$} & 0 & 6 & 0 & 0 \\
\hline & & \multicolumn{4}{|c|}{6} \\
\hline
\end{tabular}


Tabel 3. Kriteria Kesiapan Non Fisik

\begin{tabular}{|c|c|c|c|c|c|}
\hline No. & KRIIERU & $\begin{array}{c}\text { Sudah ada } \\
\text { dan } \\
\text { berjalan } \\
\text { baik } \\
\text { (akor 4) }\end{array}$ & 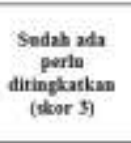 & $\begin{array}{l}\text { Belum ads biva } \\
\text { diupayakan } \\
\text { dengan } \\
\text { Kerjasan } \\
\text { axalkebolders } \\
\text { (tkor 2) }\end{array}$ & $\begin{array}{l}\text { Belam ada } \\
\text { tidak bika } \\
\text { dispazakaza } \\
\text { (skerl) }\end{array}$ \\
\hline 1 & 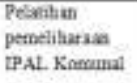 & & & $\sqrt{ }$ & \\
\hline 2 & $\begin{array}{l}\text { Pelmiana } \\
\text { pemeliharaza } \\
\text { hidoponite }\end{array}$ & & & $\sqrt{ }$ & \\
\hline & \multirow{2}{*}{$\begin{array}{l}\text { JUML.AH } \\
\text { SKOR }\end{array}$} & 0 & 0 & 4 & 0 \\
\hline & & \\
\hline
\end{tabular}

Perhitungan kesiapan ditentukan dari persentase skor yang diperoleh dari skor maksimal. Skor maksimal diperoleh dari skor maksimal kriteria fisik sebesar 8 ( skor maksimal 4 untuk 2 kriteria) dijumlah dengan skor maksimal kriteria non fisik sebesar 8 ( skor maksimal 4 untuk 2 kriteria). Sehingga tingkat kesiapan dihitung dari persentase skor yang diperoleh dari skor maksimal (16). Dari hasil telaah pada tabel 4.3 dan 4.4 diatas, diperoleh skor kesiapan fisik 6 dan skor kesiapan non fisik 4 sehingga total skor 10. Tingkat kesiapan diperoleh $63 \%$.

\section{KESIMPULAN}

Kegiatan abdimas pada RT 4 RW 8 Kelurahan Bareng menghasilkan pemahaman masyarakat tentang pemanfaatan efluen IPAL Komunal untuk hidroponik. Kegiatan ini akan berlanjut dengan kegiatan evaluasi efluen IPAL Komunal Purworupo RT 4 RW 8 Kelurahan Bareng untuk dilakukan kajian pemanfaatannya sebagai media hidroponik dengan pilihan jenis tamanan sesuai dengan keinginan warga yang disampaikan pasa kegiatan sosialisasi.

Upaya pemanfaatan efluen IPAL Komunal Purworupo akan dilakukan dengan keterlibatan akademisi dalam kegiatan fisik dan pendampingan pengelolaan IPAL Komunal secara berkelanjutan. Dalam hal pendanaan, kegiatan ini juga telah diajukan dalam hibah kegiatan abdimas Ristekdikti melalui Program Kemitraan Wilayah tahun 2019. Diharapkan kegiatan dapat berjalan dengan baik sesuai dengan tujuan yang diharapkan yaitu terwujudnya pengelolaan air limbah dan pengelolaan kualitas air sungai dengan peran serta aktif masyarakat dan akademisi.

\section{REFERENSI}

Panduan Pelaksanaan Penelitian dan Pengabdian Kepada Masyarakat 2016, LPPM ITN Malang , 2016.

Hendriarianti, Evy dan Nieke Karnaningroem. 2015. Hasil Evaluasi Kinerja IPAL Komunal USRI disepanjang DAS Brantas Kota Malang. Hibah Bersaing Dikti 2015.

Hendriarianti, Evy. 2017. Penurunan Nutrien Amoniak Dan IPAL Komunal Tlogomas Dengan Fitoremediasi. Laporan Akhir Penelitian Internal ITN Malang.

Istiqomah, Siti. 2007. Menanam Hidroponik. Jakarta: Azka Mulia Media.

www.unep.or.jp/Ietc/Publications/Freshwater/FMS2/ 1.asp diakses 10 Januari 2018. 